\title{
A Skopos-theoretical Analysis of Political Texts from English into Persian: The Case of Donald Trump's Executive Orders
}

\author{
Hamidreza Abdi \\ Freelance Researcher, Iran
}

\begin{abstract}
The present study attempted to investigate Schjoldager's (2008) taxonomy of translation microstrategies applied by the translator for translating "Donald Trump's Executive Orders." This led to determine the most/least microstrategies and translation macrostrategy employed by the translator as well as his success in producing the TT and in fulfilling the skopos of the translation. To achieve this, 20 English versions of "Donald Trump's Executive Orders" were chosen as the sample of analysis and compared with their Persian translations. As the results indicated, among Schjoldager's translation microstrategies, the translator employed all 12 strategies. This includes direct transfer, calque, direct translation, oblique translation, explicitation, paraphrase, adaptation, addition, condensation, substitution, deletion, and permutation of which explicitation and direct transfer were the most/least used microstrategies. Based on the findings, TT-oriented strategies have been used more than ST-oriented ones. Thus, under the skopos theoretical approach, the translator was successful in translating "Donald Trump's Executive Orders" and in fulfilling the skopos of the translation. This was because of that translations made by him were easy to understand to all types of TT readers. This study offers some helpful pedagogical implications to translation students and trainees, teachers, and those responsible for teaching students and training translators.
\end{abstract}

Index Terms - translation, cultural terms, and skopos theory

\section{INTRODUCTION}

Translation plays the main role in introducing the history of human social life. Mardirosz (2014) stated that through the enlarged thoughts and the application of the outcomes of other fields, it is proved that translation is not just the process of replacing the target language (TL) word with the source language (SL) word, "but a more creative activity that enriches the source text with new ideological and cultural features" (p. 160). It is common that people from different countries do things in different ways and culture is one way to these variations in behavior according to Francesco and Gold (1998). Along with conveying linguistic elements, translation, as Davaninezhad (2016) stated, transfers both social and cultural factors. As a result, a translator needs to know about the culture of other countries to produce high quality translations.

Translation is involved in most communicative activities, such as political and economic activities. In the former, translation can be used to deal with asymmetrical cultural exchanges (Venuti, 1995). In addition, translation, as he noted, plays the significant role in diplomacy and national policy-making. Schäffner and Bassnett further stated that they are politicians who decide what texts should be translated from and into which languages. They believed that "any human community is determined by interaction and relationships, such as power relationships" (p. 2). It implies the noticeable effect the power relationships have on creating international communication.

Kuhiwczak and Littan (2007) stated that political texts are hybrid texts because they cover various types of texts and genres. They may include "religious, law, advertising, educational, scientific or some other text types" (Abdel, 2015, p. 120). Furthermore, political texts provide all the information needed by a community in the political arena (Schäffner, 2004). That is why political texts are known as one type of sensitive texts. Cultural gaps are the other important factors that make political texts more sensitive. In this context, Qassem (2014) believed that such cultural gaps "are represented in differences in situations, concepts, ideas and behaviors between the SL and the TL communities" (p. 241).

The task of the translator becomes more difficult when he wants to choose an appropriate translation method as well as translation microstrategies to deal with such texts which have a defined purpose. This task that the translator should handle is well elaborated by Vermeer's (1989/2000) skopos theoretical model. Vermeer explained that the task of the translator is to translate the text according to the commission and to the final translation the extent to which he is the one who defines the exact specified skopos. Therefore, as he mentioned, the translator, as an expert, can decide how to translate the ST and what role should be given to the ST in the translation action. Schjoldager (2008), who developed a practical skopos-theoretical model of analysis, stated that skopos theory is included in the branch of translation theory which is known as applied translation studies. In a sense, it not only pays attention to pragmatic aspects of translation, but also appraises the concept of translation itself. 
Schjoldager (2008) presented a taxonomy of microstrategies that supplies translators with a set of reliable tools which gives them the opportunity to determine appropriate translation microstrategies. Thus, under her skopos theoretical approach, the overall goal of the present study was to investigate the translation microstrategies used by the translator in the translation of "Donald Trump's Executive Orders" which led to discover the translation macrostrategy applied by him. Furthermore, it is intended to find out the translator's success in producing the TT and in fulfilling the skopos of the translation. In the light of skopos theoretical approach, the researcher answered the following questions:

1. Within the Skopos theoretical model presented by Schjoldager (2008), what microstrategies have been used by the translator in the translation of "Donald Trump's Executive Orders"?

2. To what extend was the translator successful in producing the TT and in fulfilling the skopos of the translation?

\section{REVIEW OF THE RELATED LITERATURE}

\section{A. Translation from Different Points of View}

Translation has been defined by Grant Showerman (1916) as "meddling with inspiration;" whereas Harry de Forest Smith (1959) believed that "a translation of a literary work is as tasteless as a stewed strawberry" (cited in Nida, 1964, p. 1). Translatorship is a term used by Toury (1977) for translation because translation, in general, should have a social role to accomplish a function accepted by people of that country in such a way that it "is deemed appropriate in its own terms of reference" (p. 198). He further stated that culture should be taken into account as the important factor in each translation. In the socio-cultural situation, translation is defined as "subject to constraints of several types and varying degree" (p. 199).

Forghan-Parast (2008) believed that translation is " a controlled transfer of information-including, but not restricted to meaning-from a source text, producing a target text in another language" (p. 13). Based on the three key notions in his definition, he explained that translation is "a process of transfer, an action and not an object per se" (p. 14). Fischer and Jensen (2012) believed in the presence of power in translation and discussed that power in translation is encountered with limitations from different perspectives, such as hegemony, norms, language, and target group. It does not distinguish between the powerful and the powerless, "but rather makes translation implicitly or explicitly partisan" (p. 11). Thus, translation can be described as

An image of the original, particularly for those who have no access to the reality of the original. This image can undoubtedly be very different from the truth, insofar as the translator can distort and manipulate reality because he is under the pressure of a series of constraints [...] typical of the cultures to which he belongs. (Fischer \& Jensen, p. 12)

For Schjoldager (2008) a translation is "a text that expresses what another text has expressed in another language" (p. 19). She somehow pointed to the concept of house's overt and covert translations in which the target reader of the translation may not know something he is reading is a translation. In general, something derived from the above definition may refer to the fact that the concept of translation implies the academic discipline that deals with the problems relating to translations (product) and translating (process) (Munday, 2001).

\section{B. Political Texts}

The aim of political text is to exert profound influence on a specific group of people on a political level (Gusman, 2015). He further argued that a political text is heavily dependent on the political and social changes which cause linguistic features of the society to change. Novikova (2001) stated that the most important factors which characterize and define political texts are communicative, informational and political strategies. She believed that a political image of a certain country is expressed by political texts. That is, the phenomena that are objectively determined from the positive or negative point of view, as she argued, can be defined by the author of the text.

In this context, Subbotina (2015) discussed that authors, who make social and political texts, "have their own social status and political bias towards the events, introduce their point of view, personal appraisal and judgments while writing the articles" (p. 51). In this way, the information, as she stated, is subjectively interpreted via the author's point of view. Moreover, the author of the text, as she discussed, can employ different types of strategies, such as lexical, stylistic, and grammatical features to express the pragmatic function of the text. Furthermore, the author can also use "complex syntactic structures and compound sentences, stylistic devices: metaphors, metonymies, oxymoron etc" (Subbotina, p. 51).

Today, one important translation for the community is political translation because of the significant role it plays in international communication (Gusman, 2015). From a practical point of view, "political translation depends on wide knowledge of the translated topic, understand the text, and analyze it" (Arabiyat, 2016, p. 34). These requirements, as he mentioned, enable the translator to be faithful to the transference of the functional meaning, including connotation and contextual aspects, in order to achieve the purpose of the ST writer. To translate political texts, Nord (2005) proposed a model and added some complementary factors to it. According to her, the model needs to be "(a) general enough to be applicable to any text and (b) specific enough to take account of as many generalizable translation problems as possible" (p. 2).

In this regard, Yang (2012) proposed some techniques for translators who should observe in political translation. First of all, the translator is in need of the discourse analysis of translation and of the analysis of the political meanings 
through "reading between the lines" (p. 12). Then, methods used by the translator should not be restricted to linguistic forms, especially in the translation of idioms, allusions, myths and fables in political contexts. In such cases, the translator should understand the difference between the cultural connotations and political orientations of two cultures and languages and apply a "mixed translation method" (p. 14). Next, the translator must know inconsistencies in historical cultures, national customs, feelings, and ideologies between the languages. In addition, the translator should be well familiar with foreign policy and make sure about "political correctness" (p. 15). And finally, Yang pointed to the special use of grammatical phenomena and rules. He pointed to the fact that the political text is of very high quality and political sensitivity which is heavily oriented towards policy.

\section{Schjoldager' Skopos Theoretical Model}

According to Schjoldager (2008), one advantage of skopos theory is its acknowledgement that the translator is an expert specialist within the field of translation. Thus, it should bear in mind that the translator, as she stated, is an expert who works under market conditions and his task is to accomplish translations for customers. It implies that the task of the translator is to produce translations based on the 'translation briefs', given by the commissioner, a person who paid for translation. Along with the role of the commissioner, there are many other roles in the translation process, namely the initiator, the ST producer, the ST sender, the TT sender and so on. This advantage of skopos theory gives the translator the opportunity to know the role he has in the translation process.

The skopos of the TT is something that the translation action itself needs to be accomplished based on it (Schjoldager, 2008). She explained that by considering the skopos and analyzing both the ST and TT, according to a specific model, it may be possible to find out how a macrostrategy applied by the translator is close to the original ST, which refers to the translator's ST-oriented approach, or to the TT, which points to his TT-oriented approach. When the translator, as she expressed, selects the macrostrategy of the translation, he can choose several microstrategies on the basis of the goal of the translation. Schjoldager proposed taxonomy of macro and microstrategies which the first six were ST-oriented microstrategies and the rest TT-oriented ones. Here, Schjoldager's microstrategies are presented as follows:

1- Direct transfer: it as a direct transference of an ST item into the TT without any changes. For example, "Federal" to "فر ال"

2- Calque: is the transference or close translation of the structure of an ST element that leads to TT elements which are unidiomatic. For instance, "a registered lobbyist" to "لابيكر ثبت شده"

3- Direct translation: is the word-for-word translation of the ST item. It differs from the calque in that direct translation produces the TT element which is idiomatic and correct. For example, "executive order "to" "فرمان اجر ايیى

4- Oblique translation: it is different from Vinay and Darbelnet's oblique translation in that Schjoldager's oblique translation covers the contextual meaning rather than entire meaning, such as linguistic meaning, of a given ST item. For example, "blocked" to "محروم ساخته است"

5- Explicitation: A translator makes implicit information explicit "by explaining something more thoroughly." For example, "prevent taxpayer-funded bailouts" to " از كمك هاى مالى تامين شده از راه ماليات ماليات دهندكان جلوكيرى مى " كند

6- Paraphrase: is a completely and freely rendering of the meaning of the ST element into the TT in such a way that "it can be difficult to see exactly how they are rendered." For instance, "regulatory Cap for fiscal year 2017" to "تنظيم سقف هزينه ها براى سال مالى

7- Adaptation: reproducing the effect of the ST item. One aspect of the ST item may be covered through this reproduction rather than other aspects. For instance, " regime" to "نظام"

8- Addition: adding a unit of meaning to the TT. "The difference between this and explicitation is-in theory, at least- that this unit of meaning cannot be (directly) inferred from the ST itself". For example, "the Secretary of the Treasury (Secretary) shall immediately... to " "وزير خز انه دارى (كه از اين بِ وزير خوانده مى شود) مى باسيت فورى..

9- Condensation: translate as short as possible or "make explicit information implicit." For example, "the "اختيار اتى قانونى به اداره اجر ايى" to "إن "

10- Substitution: is to change the meaning of the ST which leads to the TT with different content. For example, " value to the Nation " to "جايگاه آن براى كشور"

11- Deletion: leaves out a unit of meaning. For example, ethics commitments by executive" to "جعهدات اخلافى كاركنان " شاخه اجر ايى :

12- Permutation: translate in a different place. For instance, "Commissioner of U.S. Customs and Border Protection" to "كمسيونر كمرك و حفاظت مرزى آمريكا"

\section{METHOD}

\section{A. Corpus}

The corpus of this study included 20 English versions of "Donald Trump's Executive Orders" as a sample of analysis, and their Persian translations. The aim of these executive orders, which were published in the Federal Register, was to provide the opportunity for officers and agencies of the executive branch to manage the operations within the federal government itself. Executive orders alongside Presidential memoranda, Presidential determinations, Presidential 
proclamations, Presidential notices, and Presidential sequestration orders are compiled by the Office of the Federal Register and are printed by the Government Printing Office. They are published daily, except on federal holidays. A free source of these documents is the Federal Register, which contains government agency rules, proposed rules, and public notices.

\section{B. Procedure}

To conduct the study, the following steps were taken. At first, 20 English versions of "Donald Trump's Executive Orders" were selected conveniently from NBC NEWS official website < www.nbcnews.com >, and their Persian translations from the official website of TASNIM NEWS < www.tasnimnews.com>. The rationale behind choosing such texts was that they contained many cultural phenomena, expressions, and also particular purposes which pose dramatic problems for the translator when making an attempt to transfer the meaning and concept of political expressions. In addition, when the translator encounters with such a sensitive text, this opportunity is provided to find out whether his personal opinion about the text affects the translation or commissioner and power relations produce some effects on the final product. Then each text alongside its translation was carefully investigated to extract political expressions and their corresponding equivalents. Finally, Schjoldager's (2008) taxonomy of microstrategies was applied to determine translation strategies employed by the translator to translate the 20 exclusive orders. This led to discover the overall strategy of the translator on macro level. Moreover, the frequencies and percentages of translation strategies employed by the translator illustrated in tabulation forms, and the relation between the microstrategies and the number of them was estimated through Chi Square test (X2).

\section{RESULT AND DISCUSSION}

As Table 1 indicated, the translator employed all Schjoldager's (2008) microstrategies to translate the 20 exclusive orders of which explicitation $(n=165)$ and direct transfer $(n=5)$ were the most/least used strategies respectively.

TABLE I.

FreQuencIES AND PERCENTAges OF MiCROSTRATEGIES USED By THE TRANSLATOR FOR

TRANSLATING THE 20EXCLUSIVE ORDERS
\begin{tabular}{|l|c|c|}
\hline Microstrategies & Frequency & Percentage \\
\hline Explicitation & 165 & 20.0 \\
\hline Direct translation & 155 & 19.0 \\
\hline Adaptation & 105 & 13.0 \\
\hline Deletion & 95 & 12.0 \\
\hline Permutation & 91 & 11.0 \\
\hline Addition & 65 & 8.0 \\
\hline Calque & 50 & 6.0 \\
\hline Paraphrase & 41 & 5.0 \\
\hline Oblique translation & 19 & 2.0 \\
\hline Condensation & 15 & 2.0 \\
\hline Substitution & 12 & 1.0 \\
\hline Direct transfer & 5 & .5 .0 \\
\hline Total & 818 & 100.0 \\
\hline
\end{tabular}

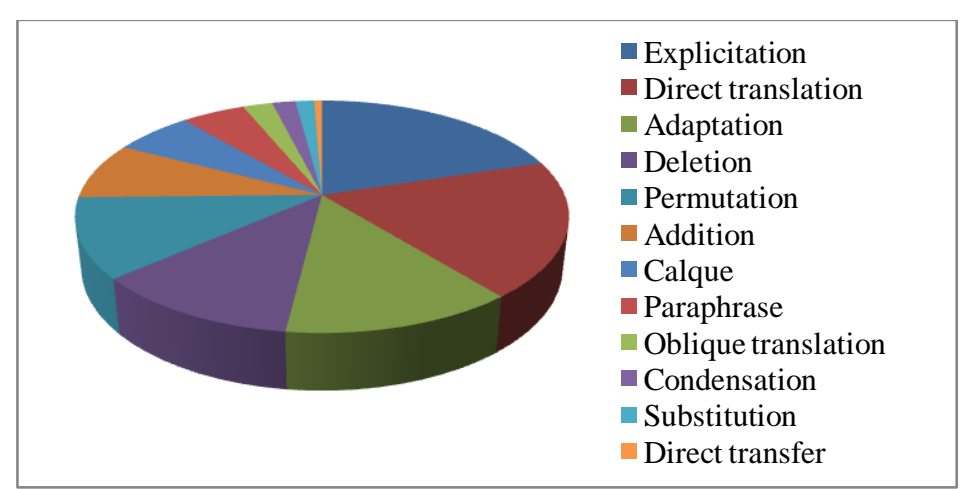

Figure 1. Microstrategies used by the translator for translating the 20 exclusive orders

Table 2 shows the frequent use of both ST- and TT oriented strategies by the translator to translate the 20 exclusive orders. 
TABLE II.

FREQUENCIES OF BOTH ST- AND TT-ORIENTED STRATEGIES USED By THE TRANSLATOR

\begin{tabular}{|c|c|c|c|c|c|}
\hline ST-Oriented Strategies & Frequency & Percentage & TT-Oriented Strategies & Frequency & Percentage \\
\hline Direct translation & 155 & 74.0 & Explicitation & 165 & 27.0 \\
\hline Calque & 50 & 24.0 & Adaptation & 105 & 17.0 \\
\hline \multirow[t]{7}{*}{ Direct transfer } & 5 & 2.0 & Deletion & 95 & 16.0 \\
\hline & & & Permutation & 91 & 15.0 \\
\hline & & & Addition & 65 & 11.0 \\
\hline & & & Paraphrase & 41 & 7.0 \\
\hline & & & Oblique translation & 19 & 3.0 \\
\hline & & & Condensation & 15 & 2.0 \\
\hline & & & Substitution & 12 & 2.0 \\
\hline Total & 210 & 100.0 & Total & 608 & 100.0 \\
\hline
\end{tabular}

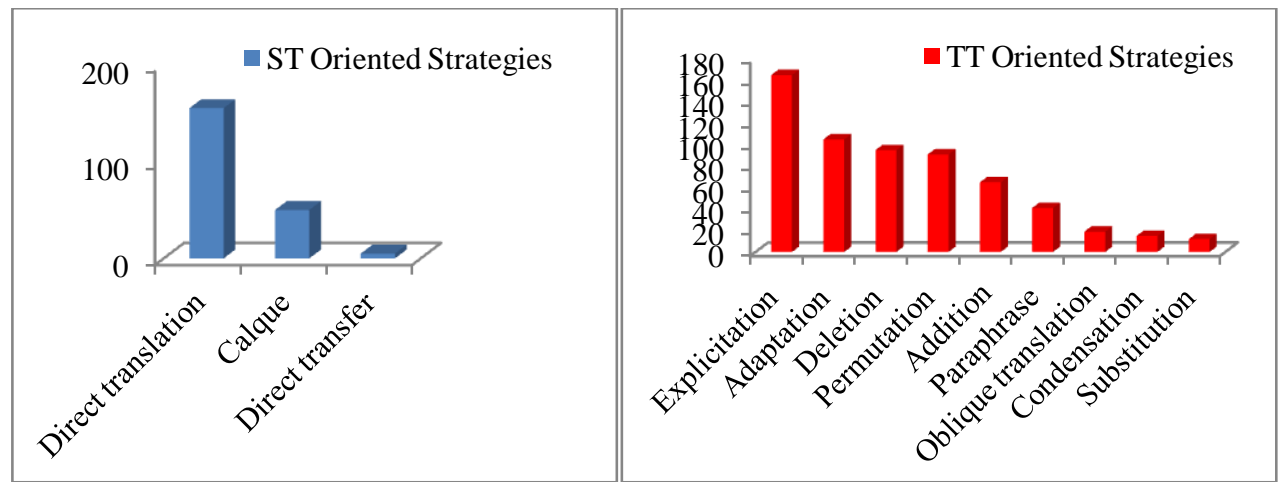

Figure 2. ST- and TT-oriented strategies used by the translator

According to Table 2, the total number of TT-oriented strategies $(N=608)$ was higher than the total number of SToriented ones $(N=210)$.

\section{A. Chi Square Test}

W.Best and V.Kahn (2006) discussed that a chi square (X2) is not used to measure values but to discrete data, counted. They further stated that the $X 2$ "is not a measure of the degree of relationship"; it is only applied to evaluate the probability that "some factor other than accounts for the apparent relationship" (p. 434). In another word, the probability that the observed relationship derived from the chance, as they noted, is estimated through the $X 2$. Thus, the researcher ran the $X 2$ to see whether the relation between microstrategies and the number of them is significant.

According to the results obtained from $X 2$, there is not a significant relationship between microstrategies and the number of them at the 0.05 level of significance $(p=.645, p>.05)$. Thus, the null hypothesis is not rejected and it is accepted at the .05 level of significance.

\section{B. Discussion}

In the first rule of Reiss's and Vermeer's (1984, cited in Munday, 2001) skopos theory, the emphasis is strongly on the TT (or Translatum) which is determined by the skopos. It alludes to the fact that the purpose of the TT is the most important factor in choosing translation macro and microstrategies. In this context, Nord (1997) argued that the first step, in her process model, is to analyze and express the translation brief and to establish the skopos of the translation. Thus, this is important to investigate the skopos of the TT if it is intended to answer the last question of the present study which is: to what extend has the translator been successful in producing the TT, and in fulfilling the skopos of the translation?

Based on skopos theory, the translator plays the main role "in a process of intercultural communication and production of the translatum" (Munday, 2001, p. 80). Thus, the translator should make an attempt to translate the ST to the extent that all the TT readers are able to understand the text even if they have limited knowledge about the terminology of that text. In this way, it can be claimed that the skopos of the translation has been accomplished and the translator has been successful in choosing microstrategies and the overall strategy on macro level.

In the case of "Donald Trump's Executive Orders," the success of the translator was heavily dependent on microstrategies he employed to overcome political items and then on the macrostrategy he applied to the whole text. As the results indicated, in order to translate the 20 executive orders, the translator employed all Schjoldager's (2008) microstrategies, including direct transfer, calque, direct translation, oblique translation, explicitation, paraphrase, condensation, adaptation, addition, substitution, deletion, and permutation. By contrast, in the same study done by Jensen (2009), only 6 strategies out of 17 proposed by Schjoldager have been applied by the translators. This includes direct transfer, calque, direct transfer, oblique translation, explicitation, and paraphrase.

As the results showed, the first three of Schjoldager's (2008) microstrategies are ST-oriented and the rest TT-oriented ones. That is to say, the frequent use of ST-oriented strategies leads to TT orientation on macro level and vice versa. Do 
not buy into the idea that the frequent use of one strategy, for example permutation as a TT-oriented strategy, gives the indication of the translator's TT orientation on macro level. According to the results, the translator's strategy on macro level was TT-oriented and the translations produced by him were understandable to all types of target readers; whereas in Jensen's (2009) study, the overall strategy of the majority of the participants was ST-oriented which implies their faithfulness to the ST structure. In another study conducted by Hansen (2010), the participants applied both ST- and TT-oriented strategies, such as direct translation and oblique translation. This alludes to the fact that the translators' strategy on macro level was a mixt strategy of both ST and TT.

\section{CONCLUSION}

As the results indicated, the translator applied TT-oriented strategies for smallest units which led to his TT orientation on macro level. Thus, under the skopos theoretical approach, the researcher concluded that the translator was successful in producing comprehensible translations and in communicating with target readers because the important purpose in translating political texts, such as "Donald Trump's Executive Orders," was, first, to inform target readers about what was going on the word and what decisions were made by other countries; and then to exert considerable influences on the target readers. "Donald Trump's Executive Orders" have important massages, ranging from threats and sanctions to peace and prosperity for the people of the United State and the word, which should be discovered and transferred correctly to the target readers.

The results of the study identified some pedagogical implications which can be helpful to translation students and trainees, teachers, and those responsible for teaching students and training translators. Some of these implications are discussed as follows:

According to the skopos theory, the translator has not been forced to produce the TT with the same functional equivalence as the ST. The function of the translation, as Vermeer (1989/2000) discussed, is determined by the skopos and the brief of the translation. Thus, it is important to pay special attention to these two important factors, and choose microstrategies on the basis of them. It is recommended that translators, translation students and trainees need to obey the brief which is defined by the commissioner or the public and don't act on his own. Universities, where translation courses are held in both undergraduate and postgraduate degrees, as well as translator training institutions are responsible for teaching students and training translators should supply all relevant facilities and employ qualified teachers in the field. Teachers can give the brief to the students and ask them to translate for the brief not for the grade. Furthermore, they should make students and trainees aware of the importance of the brief. It causes them to be familiar with the brief and its importance and to be prepared for translating in this profession.

\section{REFERENCES}

[1] Abdel-Hadi, O. S. M. (2015). Analysis of political language and translation: A case study of Obama's two political speeches (in Cairo 2009 and in Jerusalem 2013). Unpublished M.A. thesis. An-Najah National University.

[2] Arabiyat, T. A. (2016). Theories and strategies of translation of political nuclear tests in the Jordanian Senate. Journal of Power, Politics \& Governance 4.1, 17-46.

[3] Davaninezhad, F. K. (2016). Supplementary practices and decreasing translation problems in translating political English news texts into Persian. Theory and Practice in Language Studies 6.1, 184-193.

[4] Fischer, B. \& Jensen, M. N. (2012). The power of translation. In B. Fischer \& M. N. Jensen (eds.), Translation and the reconfiguration of power relations: Revisiting role and context of translation and interpreting. Berlin: LIT-VERLAG, 9-14.

[5] Forghan-Parast, F. (2008). Towards a cybernetic model of translation. In A. Pym \& A. Perekrestenko (eds.), Translation research projects 1 . Spain: Tarragona, 13-25.

[6] Francesco, A. \& Gold, B. (1998). International organizational behavior: Text, reading, cases, and skills. New Jersey: PrenticeHall.

[7] Gusman, M. (2015). Features of the political texts' translation. https://prezi.com/zxw-uyktiwto/features-of-the-political-textstranslation/ (accessed 25/3/2019).

[8] Hansen, L. (2010). Translation of political speeches: A skopos-theoretical analysis. Unpublished M.A. thesis. Aarhus University.

[9] Jensen, M. N. (2009). Professional translators' establishment of skopos: A 'brief' study. Unpublished M.A. thesis. Aarhus University.

[10] Kuhiwczak, P. \& Littan, K. (eds.) (2007). A companion to translation studies. Clevedon, Multilingual Matters.

[11] Mardirosz, S. K. (2014). Problems related to the translation of political texts. Acta Universitatis Sapientiae, Philologica 6.2, 159-180.

[12] Munday, J. (2001). Introducing translation studies: Theories and applications. London: Routledge.

[13] Nord, C. (2005). Text analysis in translation: theory, methodology and didactic application (2nd edn.). Amsterdam: Rodopi.

[14] Nord, C. (1997). Translating as a purposeful activity. Manchester: St. Jerome Publishing.

[15] Novikova, Y. (2001). Evaluation as a pragmatic factor of a political discourse of a newspaper publicism of Germany. Proceedings of a Scientific Session of VolGU 1, 69-77.

[16] Qassem, M. A. (2014). The Arab translation students' hindrances in translating political culture from English into Arabic. AWEJ 5.4, 240-253.

[17] Schäffner, C. (2004). Political discourse analysis from the point of view of translation studies. Journal of Language and Politics 3.1, 117-150. 
[18] Schjoldager, A. (2008). Understanding translation. Århus: Academica.

[19] Subbotina, V. (2015). Pragmalinguistic aspect of social and political texts. The European Proceedings of Social \& Behavioural Sciences, 48-62.

[20] Vermeer, H. J. (1989/2000). Skopos and commission in translational action. In L. Venuti, (ed.), The translation studies reader. Oxon: Routledge, 221-249.

[21] W. Best, J. \& V. Kahn, J. (2006). Research in education (10th edn.). New York: Pearson.

[22] Yang, M. (2012). The principles and tactics on diplomatic translation: A Chinese perspective. Babel 58.1, 1-18.

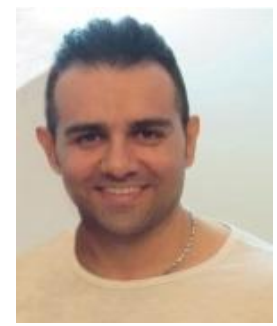

Hamidreza Abdi has MA in Translation Studies from Azad University, Science and Research, Tehran, Iran in 2016. He received his BA in the same major from Azad University, Roodehen, Iran in 2009. He is a freelance researcher in the field of Translation Studies. His main interest is research in translation and technology. 